УДК 636.22/.28:612.59(477.65)

(C) 2015

Гончарова I. І., кандидат сільськогосподарських наук

Харківська державна зооветеринарна академія

\title{
ЗДАТНІСТЬ ТЕЛИЦЬ М'ЯСНИХ ПОРІД ДО ВІДТВОРЕННЯ ЗАЛЕЖНО ВІД РІВНЯ ГОДІВЛІ
}

\section{Рецензент - доктор сільськогосподарських наук, професор Ю. Д. Рубан}

\begin{abstract}
Викладено результати живої маси $і$ відтворювальної здатності телиць знам'янського внутрішньопородного типу поліської м'ясної породи з різним рівнем годівлі. Встановлена оптимальна жива маса $i$ вік плідного парування телиць. Так, інтенсивне вирощування телиць забезпечує середньодобовий приріст 700 г, живу масу 385 кг у 15-16-місячному віиі. Експериментально встановлено, щзо інтенсивно вирощені тварини за весь період вирощування щзоденно споживали менше кормів, також відмічалися кращчою відтворювальною здатністю, вік плідного парування у них на 146 діб був менше, ніж у ровесниць контрольної групи. Показники заплідненості у них були вищими на 6\%. Ці телиці на 4-5 місяџів були молодшими на момент плідного парування, щзо свідчить про вищу скоростиглість інтенсивно вирощзених телицьь.
\end{abstract}

Ключові слова: відтворювальна здатність, жива маса, ремонтні телиці, рівень годівлі, інтенсивне вирощування, парування.

Актуальність проблеми. У м'ясному скотарстві в порівнянні з молочним проблема відтворення стоїть гостро. Тут єдиною продукцією корови м'ясної породи $є$ теля, що вирощується до від'єму (6-8-місячного віку). Для відтворення стада найважливіше значення має проблема вирощування ремонтних телиць і вік їх покриття. Практично в усіх господарствах телиць злучають у віці 2-х років і старше, а тому витрати на ïx вирощування і утримання починають відшкодовуватися тільки в 3-річному віці (приплід), що знижує чисельність і зростання поголів'я й уповільнює темпи селекції. У м'ясному скотарстві оптимальна система вирощування молодняка не розроблена. Ріст і розвиток телиць крупних м'ясних порід (української м'ясної, шаролє) вивчали Г. А. Глотова, А. М. Угнівенко, Л. В. Гончаренко, В. Г. Василець. Встановлено, що оптимальним строком парування цих телиць $\epsilon$ вік у межах 22-27 місяців, що знижує ефективність м'ясного скотарства. Щодо середньоскоростиглих і скоростиглих порід, як абердин-ангуська, герефордська, знам'янський внутрішньопородний тип поліської м'ясної породи, то їх відтворювальна здатність $є$ мало дослідженою. Тому проблема прискореного розвитку м'ясного скотарства за рахунок раціонального вирощування i використання ремонтних телиць м'ясних порід $\epsilon$ актуальною, а iї рішення має велике народногосподарче значення $[1,2]$.

Метою роботи було порівняльне вивчення різної інтенсивності вирощування ремонтних телиць та пошук оптимального варіанта.

Для досягнення цієї мети були поставлені такі завдання: встановити вплив різної інтенсивності вирощування ремонтних телиць на витрати кормів на одиницю приросту; встановити оптимальний вік запліднення телиць.

Методика досліджень. Для дослідів були підібрані 2 групи ремонтних телиць знам'янського внутрішньопородного типу поліської породи по 12 голів у кожній. Телиці всіх дослідних груп після відлучення вирощувалися за рівнем інтенсивності: I - контрольної - 1,57; II - 1,75. Раціон телиць у всіх групах як за набором кормів, так і за їх якістю був ідентичним і збалансованим за всіма поживними речовинами, згідно 3 нормами годівлі молодняка був розрахований на отримання середньодобового приросту живої маси з моменту відлучення до злучки у телиць I групи - 400 г, II - 700 г. Різну інтенсивність вирощування досягли за рахунок введення в раціони різної кількості зернових концентратів (з часу відлучення і до злучного віку): 2,0 кг в раціоні контрольної (I) групи, 3,0 кг - в раціонах дослідної II групи.

Пасовищний корм враховували методом зворотнього перерахунку. Визначали чисту і обмінну енергію, необхідну на підтримку життя, за рекомендаціями В. В. Цюпко (1989). 3 урахуванням цього розрахували кількість енергії корму, необхідної на підтримуючий обмін.

Відтворну здатність оцінювали за показником плідного осіменіння. Заплідненими вважали тих телиць, які впродовж двох останніх місяців не приходили в охоту після злучки.

Результати досліджень. Годівля була достатньо повноцінною як за поживними речовинами і за кількістю перетравного протеїну, так і за вмістом в раціоні мінеральних речовин і вітамінів (табл. 1). 
СІЛЬСЬКЕ ГОСПОДАРСТВО. ТВАРИННИЦТВО

1. Витрата кормів під час вирощування телиць від народження до злучного віку на одну голову, кг

\begin{tabular}{|c|c|c|}
\hline \multirow{2}{*}{ Корма, кг } & \multicolumn{2}{|c|}{ Група } \\
\cline { 2 - 3 } & I & II \\
\hline Молоко & 1183,3 & 1205,1 \\
\hline Пасовищний корм & 2842,0 & 1275,0 \\
\hline Сіно різнотравне & 720,0 & 747,0 \\
\hline Сінаж & 594,0 & 545,0 \\
\hline Солома & 513,0 & 450,0 \\
\hline Меляса & 189,0 & 163,8 \\
\hline Концентрати & 885,0 & 795,0 \\
\hline Силос & 2236,0 & 1933,0 \\
\hline У кормі міститься: кормових од. & 3232,0 & 2677,0 \\
\hline Перетравного протеїну & 316,7 & 267,0 \\
\hline О.Е. Мдж & 36710,0 & 28617,0 \\
\hline Сухої речовини, кг & 3775,0 & 2864,3 \\
\hline Сирої клітковини, кг & 1079,0 & 678,0 \\
\hline Перетравного протеїну, г/к.од & 98,0 & \\
\hline \multicolumn{2}{|c|}{9,92} \\
\hline КОЕ, МДж/СР & 9,72 & \\
\hline
\end{tabular}

Примітка: злучний вік у телиць I групи - 20 міс.; II - 15 місяців.

Загальна витрата корму з урахуванням спожитого молока матері у I контрольній групі від народження і до 20 місяців становила 3232,0 корм. од. i 316, 7 кг перетравного протеїну, у II дослідній групі від народження до 15 місяців - 2677,0 і 267,0 кг відповідно.

Телиці II дослідної групи від народження до злучного віку спожили менше кормових одиниць і перетравного протеїну на $555(17,2 \%)$ и 49,7 кг $(15,7$ \%), ніж їх однолітки I контрольної групи.

Однак від народження і до злучного віку більше споживання обмінної енергії відмічалося в
I контрольній групі телиць - 36710,0 МДж, що на - 8093,0 МДж (22,0 \%) більше, ніж у другій, що пояснюється пізньою плідної злучкою I групи. Таким чином, тварини другої групи щоденно споживали менше кормів, ніж першої, а за весь період вирощування до першої злучки загальні витрати кормів у першій групі за рахунок подовження термінів вирощування були більшими.

Фактична інтенсивність вирощування і середньодобове споживання доступною для обміну енергії піддослідних ремонтних телиць наведені в таблиці 2.

\section{2. Ефективність використання енертії для тварин усіх груп розрахована від 8 місяців до злучного віку}

\begin{tabular}{|c|c|c|}
\hline \multirow{2}{*}{ Корма, кг } & \multicolumn{2}{|c|}{ Група } \\
\cline { 2 - 3 } & I & II \\
\hline Мінімальна конц. ДОЕ в СВ раціону, МДж & 7,8 & 8,8 \\
\hline Чиста енергія підтримки, МДж/день & 8,2 & 12,4 \\
\hline Доступна для обміну енергія на підтримання (ДОЕп) & 42,4 & 43,0 \\
\hline Спожита ДОЕ, МДж & 66,5 & 75,7 \\
\hline Відношення спожитої ДОЕ до ДОЕ на підтримання & 1,57 & 1,75 \\
\hline Коефіцієнт використання ДОЕ на підтримання (КП) & 0,654 & 0,673 \\
\hline
\end{tabular}


СІЛЬСЬКЕ ГОСПОДАРСТВО. ТВАРИННИЦТВО

3. Показники відтворювальної здатності телиць вирощених за різної технології

\begin{tabular}{|c|c|c|}
\hline \multirow{2}{*}{ Показник } & \multicolumn{2}{|c|}{ Група } \\
\hline & $\mathrm{I}$ & II \\
\hline Плідна злучка, дні & $606,0 \pm 4,89$ & $460,0 \pm 4,35^{*}$ \\
\hline Жива маса (кг): у випадку прояву першої охоти & $227,3 \pm 1,20$ & $222,3 \pm 1,65$ \\
\hline плідній злучці * & $384,0 \pm 6,29$ & $386,0 \pm 3,21$ \\
\hline Заплідненність від першої злучки, \% & 70,0 & 76,0 \\
\hline Кількість осіменінь для запліднення & 2,0 & 1,5 \\
\hline $\begin{array}{c}\text { Середньодобовий приріст у період з моменту } \\
\text { відлучення і до злучки, Г }\end{array}$ & $402,0 \pm 16,28$ & $684,0 \pm 11,96^{*}$ \\
\hline
\end{tabular}

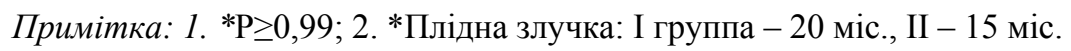

Найвищі показники ДОЕ на підтримання встановлені в II групі 43,0 МДж, а найменші в першій 42,4 МДж. Чиста енергія підтримки I і II групах становила - 12,4 і 8,2 МДж, що перевищувало значення даного показника 4,2 МДж. На підставі цих показників розраховано кількість енергії корму, необхідної на підтримуючий обмін. Найбільша кількість енергії корму відзначалася в II - 1,75, в I - 1,57, що більше на 11,4 \%. Тварини I групи споживали менше доступної для обміну енергії на добу. Водночас інтенсивність вирощування у цієї ж групи була відповідно нижче.

Таким чином, аналіз витрачених кормів свідчить про ефективність пропонованої системи високого i інтенсивно-поміркованого вирощування телиць знам'янського типу, за якої значно зменшується витрата кормів і повніше використовуються генетичні можливості тварин.

Нами проведено порівняльне вивчення відтворювальної функції знам'янських телиць за різної інтенсивності вирощування (табл. 3).

Телиці II группи майже на 4-5 місяців були молодші, а контрольна, навпаки, старше на момент плідної злучки. У тварин II дослідної групи виявляється статева скоростиглість і їх здатність в 24-25 місяці давати перший нормально розвинений приплід. Тому, незважаючи на те, що злучку телиць проводили в ранньому віці, однак у них спостерігалося по 2-3 статевих цикла.

Дослідження показали, що між телицями різних груп відзначена різниця за показником відтворювальної здатності (табл. 3). Жива маса телиць на момент плідної злучки була практично однаковою, але телиці II групи за більш інтенсивного вирощу-

\section{БІБЛІОГРАФІЯ}

1. Гончаренко Л. В., Ізвеков М. Е. Оптимальний вік першого плодотворного осіменіння телиць м'ясних порід / Л. В. Гончаренко, М. Е. Ізвеков // Проблеми зооінженерії та ветеринарної медицини : [зб. наук. праць]. - Х. : Харк. зоовет. вання досягли іï раніше. Відповідно від тварин II групи значно раніше буде отриманий приплід.

Встановлено, що найбільшу живу масу за плідної злучки мали телиці II групи, які досягли $386,0 \pm 3,21$ кг в 15 місяців. Телиці I (контрольної) групи досягли такої ж живої маси і були злучені в 20 місяців. Високий середньодобовий приріст в період 3 моменту відлучення до злучки мали телиці інтенсивно вирощеної II групи: 684,0 $\pm 11,96$, що на 282,0 г (70,1%, $\mathrm{P} \geq 0,99)$ більше, ніж у аналогів контрольної групи. Заплідненість від першої злучки була вищою у тварин II групи в порівнянні з контрольною (I) на $6 \%$. За кількістю осіменінь для запліднення телиці цих груп мали значно кращий показник. Так, кількість осіменінь для запліднення у телиць II групи було меншим на 25 \% від аналогів контрольної групи.

Таким чином, за всіма показниками відтворювальної здатності інтенсивно вирощенні телиці мали значну перевагу в порівнянні з групою, які перебували на нормованому вирощуванні.

Висновок. Інтенсивне вирощування 1,75 забезпечує середньодобовий приріст 700 г, живу масу 385 кг у 15-16-місячному віці. За умови інтенсивності вирощування $(1,57)$ таку живу масу телиці мають у 20-місячному віці. Також інтенсивно вирощені телиці II групи відзначалися кращою відтворювальною здатністю. Вік плідного парування у них на 146 діб ( $\mathrm{P} \geq 0,99)$ був менше, ніж у ровесниць контрольної групи. Показники заплідненості у них були вищими на $6 \%$. Ці телиці на 4-5 місяців були молодшими, ніж у I контрольній за плідного парування, що свідчить про вищу скоростиглість інтенсивно вирощених телиць.

ін-т., 1998. - Вип.3 (27). - С. 80-82.

2. Костенко B. Технологія вирощування ремонтних телиць / В. Костенко // Агробізнес сьогодні. - №20 (243). - 2012. - С. 20-23. 